\title{
The effects of plant cover on population of pear psylla (Cacopsylla pyricola) and its predators
}

\author{
Mohammad Saeed EMAMI ${ }^{1}$
}

Received July 17, 2016; accepted October 31, 2016.

Delo je prispelo 17. julija 2016, sprejeto 31. oktobra 2016.

\begin{abstract}
Cacopsylla pyricola (Förster, 1848) (Hemiptera: Psyllidae) is a serious pest of pear in all pear growing areas. In the scope of an integrated pest management, a two consecutive years study was carried out to determine the effects of plant cover on pear psyllid population and its predators. Two treatments including plant cover and bare ground were applied in a randomized complete block design with three replicates. The sampling of the pest and its predators were done weekly by beating technique and leaf sampling. The data were subjected to analysis of variance (ANOVA). The results showed that plant cover had significant effect on the increase of predators on the trees $(P<0.001)$. The psyllid specialist predator, Anthocoris nemoralis (Fabricius, 1794), had the highest population among the pear psyllid predators ( 0.29 per sample). Plant cover had no significant effect on reducing the population of eggs, nymphs and adults of the pear psyllid. Despite the increase in the population of predators led by plant cover, lack of their effectiveness to reduce the pear psyllid population is discussed.
\end{abstract}

Key words: Cacopsylla pyricola; pear; predator; plant cover

\section{IZVLEČEK}

\section{VPLIVI VAROVALNIH RASTLIN NA POPULACIJO MALE HRUŠEVE BOLŠICE (Cacopsylla pyricola) IN NJENE PLENILCE}

Mala hruševa bolšica (Cacopsylla pyricola (Förster, 1848) (Hemiptera: Psyllidae) je pomemben škodljivec hrušk na vseh območjih njihove pridelave. $\mathrm{V}$ okviru integriranega zatiranja škodljivcev je bil $\mathrm{v}$ dveh zaporednih letih preučevan učinek poraslosti tal na populacijo navedene bolšice in njenih plenilcev. V popolnem naključnem bločnem poskusu s tremi ponovitvami sta bili preizkušani dve obravnavanji, in sicer vpliv golih in poraščenih tal. Vzorčenje škodljivcev in njihovih plenilcev je bilo opravljeno tedensko $\mathrm{z}$ metodama udarjanja vej in vzorčenja listov. Podatki so bili obdelani $\mathrm{z}$ analizo variance (ANOVA). Rezultati so pokazali, da je imel rastlinski pokrov značilni učinek na povečanje populacije plenilcev na drevesih $(P<0.001)$. Med vsemi plenilci male hruševe bolšice je bila vrsta Anthocoris nemoralis Fabricius, 1794, najbolj številčna $(0,29$ na vzorec). Poraščenost tal pa ni imela značilnega vpliva na zmanjšanje populacije jajčec, nimf in odraslih osebkov bolšice. V prispevku je analizirana neučinkovitost plenilcev na zmanjšanje populacije bolšic, kljub povečanju njihove populacije na zemljišču z zastrtimi tlemi $\mathrm{z}$ varovalnimi rastlinami.

Ključne besede: Cacopsylla pyricola; hruška; plenilec; poraslost tal

\section{INTRODUCTION}

The Pear psylla, Cacopsylla pyricola (Förster, 1848) (Hemiptera: Psyllidae), is a host specific pest of only pears and is present in all pear growing areas with considerable economic importance (Emami et al., 2014). The adults and nymphs suck the sap from the leaves and produce large, sticky drops of honeydew that can coat the tree and fruit. Psyllid feeding can cause the foliage to wilt and drop to the ground and fruit remains undersized. Prolonged infestations may kill the tree outright (Emami, 2014). Cover crops are widely used to reduce soil erosion by wind and water (Hargrove, 1991), produce organic matter, and reduce soil compaction and crusting and thus

Plant Protection Research Department, Isfahan Agricultural and Natural Resources Research and Education Center, AREEO, Isfahan, Iran. PO Box 81785-199. E-mail: mse1480@ gmail.com 
improve water infiltration and in some cases moisture retention (Letourneau et al., 2009). Cover crops also influence pest management of arthropods, as reviewed by Bugg (1992) and Bugg and Waddington (1994). Cover crops can be categorized to resident vegetation, planting alternate strip and commercial 'insectary mixes' of plants (Bugg, 1991). Understory weeds or 'resident vegetation' become assets when managed as cover crops (Zandstra and Motooka, 1978). Weeds sometimes play an important role in pest management systems and when specific weeds are not present, biological control of certain insects is often impossible (Zandstra and Motooka, 1978). Wilde (1960) showed that clean orchard cultivation tended to reduce predator numbers and favor high psyllid populations, probably because of higher orchard temperatures and lower relative humidity than those found in orchards with plant cover. Pear psyllids are favored by hot, dry conditions and damage caused by them is particularly devastating when there are prolonged periods of dry weather (Cross et al., 2010). Orchards with ground covers may have higher populations of certain natural enemies, largely due to increased habitat and alternate food sources for beneficial insects and mites; they also may have fewer problems with pests and mites (Flint, 1998). Orchard systems contain high plant diversity and perennial multistrata designs that provide wealthy resources and habitats to living communities such as beneficial organisms (Simon et al., 2010). Research has shown an exceptionally strong relationship between higher natural enemy diversity and herbivore suppression in agricultural systems (Letourneau et al., 2009). Fye (1983) reported that cover crops in commercial pear orchards led to the build-up of generalist predators including Nabis sp., Orius sp., Geocoris sp., Hippodamia convergens Guérin-Méneville, 1842, Coccinella transversoguttata richardsoni Brown, 1962, Chrysopa spp., Hemerobius sp., and spiders. Despite the increase in the abundance of predatory and parasitoid insects led by the use of plant covers, it is still uncertain whether this will translate into reduced pest densities. In the present study, an investigation was performed on the effects of plant cover on pear psyllid and its predators in pear orchards, to determine the effectiveness of this strategy in regulating pest populations.

\section{MATERIALS AND METHODS}

\subsection{Site and plants}

Field studies were conducted in a 1-ha commercial pear orchard located at Isfahan, Iran, during the two consecutive years. The trees were 15-20 years old, Pyrus communis L. of the variety 'Shahmivea' which is the common pear variety in the study area. Plant cover was composed of a mix of resident weeds consisted of Lamb's quarters, Chenopodium album L. ( 5\%), Liquorice, Glycyrrhiza glabra L. ( $4 \%)$, Purslane, Portulaca oleraceae L. ( $3 \%)$, Prickly lettuce, Lactuca scariola L. ( $7 \%)$, Sow thistle, Sonchus asper (L.) Hill. ( $4 \%)$, Dandelion, Taraxacum officinale Weber $(\sim 8 \%)$, Wild carrot, Daucus sp. $(\sim 9 \%)$, Plantain, Plantago major L. $(\sim 6 \%)$, Couch grass, Cynodon dactylon (L.) Pers. ( $4 \%)$, Ground cherry, Physalis sp. ( 4\%), White Clover, Trifolium reprens L. $(\sim 19 \%)$ and Alfalfa, Medicago sativa L. ( $27 \%)$. Change in the percentage of plants over the experimental area was about $\pm 1 \%$. Plant cover, represented by plant species that developed naturally for circa 10 years.

\subsection{Experimental design}

Two treatments consisted of plant cover and bare ground were applied in a randomized complete block design with three replicates. Each replicate was $1600 \mathrm{~m}^{2}$ with 60 trees. Each treatment was randomly allocated in blocks. Between row of trees in bare ground treatment was kept free of vegetation by shallow tillage (10 $\mathrm{cm}$ deep). Tillage was repeated when the plant cover begin to emerge. In later treatment plant cover under the trees was removed by herbicide application. Management operations including fertilization, pruning and irrigation were applied similarly in treatments. A late-summer application of amitraz (Mitac) was made in both treatments to reduce densities of pear psylla and mites. 


\subsection{Sampling}

Ten trees in each replicate were randomly selected at each sampling time. Pear psyllid adults and predators (larva/nymph and adult) of pear psyllid were sampled using the limb-jarring technique (Burts and Retan, 1973). A beat tray $(45 \times 45 \mathrm{~cm})$ was covered with a white cloth, both to make the insect visible for counting and to act as substrate to which adult insect cling while they are being counted (Burts and Retan, 1973; McClure et al., 1982). Four limbs of a tree were randomly selected. The beat tray was held beneath the limb and it was rapped sharply three times with a section of stiff rubber hose (Horton et al., 2003). Dislodged adult psyllids and predators (adults and nymphs/larvae) which fell onto the tray were counted. Samples were taken in the morning when temperature was cool. Eggs and nymphs of psyllid were sampled by 20 randomly selected leaves per tree. The samples were separately placed into nylon labelled covers and taken to the laboratory in refrigerated containers. The upper and lower surface of the leaf was carefully examined using a stereomicroscope, where pear psyllid eggs and nymphs were counted and recorded.The sampling was initiated in early May and continued at weekly intervals until late September.

\subsection{Data analyses}

Data were square root $(\mathrm{x} \pm 0.5)$ transformed before analysis to standardize the variance. All data were subjected to a one-way analysis of variance (ANOVA) to compare the effect of treatments on pear psyllid and its predators. The comparison of means was performed using Duncan's multiple range test (DMRT) $(p<0.05)$. Data were analyzed by using SAS statistical software version 9.1. (SAS Institute Inc., 2004).

\section{RESULTS}

3.1 Population of the developmental stages of the pear psyllid

There was not a significant difference between treatments in the density of eggs, nymphs and adults of the pear psyllid (in the first year, egg: $P=$ 0.16 ; nymph: $P=0.06$; adult: $P=0.1$; in the second year, egg: $P=0.58$; nymph: $P=0.09$; adult: $P=0.1$,) (Fig. 1 and 2 ).

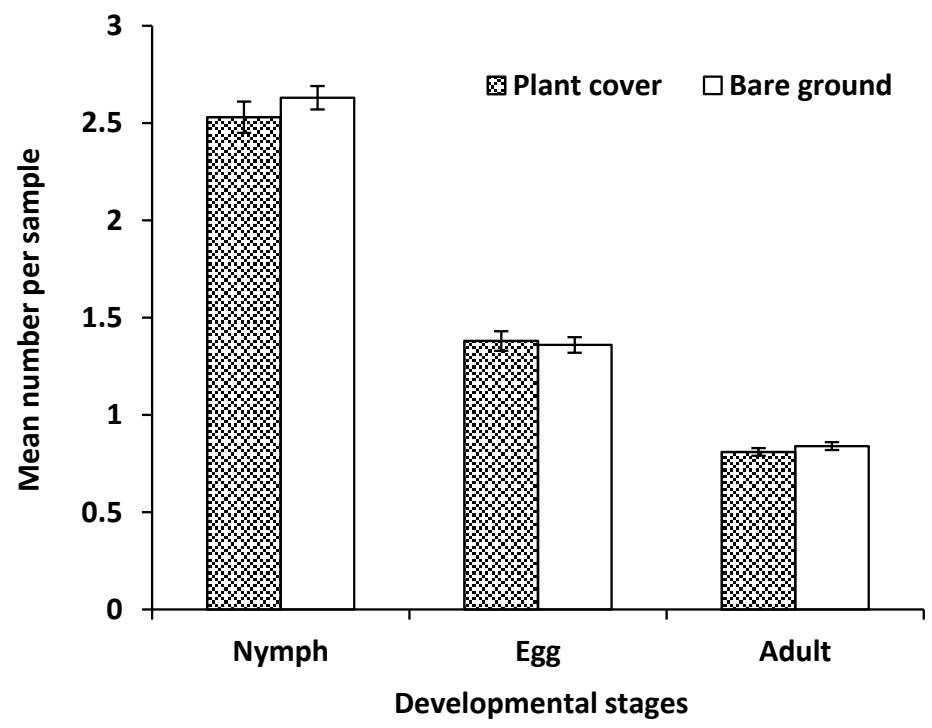

Figure 1: Mean number of developmental stages of Cacopsylla pyricola in the first year 


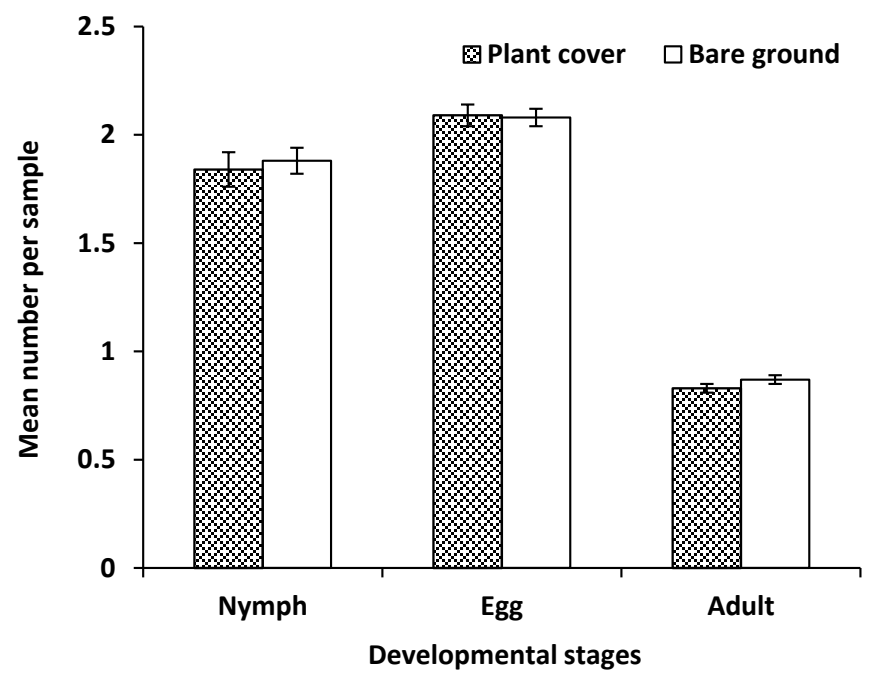

Figure 2: Mean number of developmental stages of Cacopsylla pyricola in the second year

\subsection{The population of predators}

The predators of pear psylla collected on beat tray over the duration of the study were eight species including Anthocoris nemorum Linnaeus, 1761. and A. nemoralis Fabricius, 1794 (Hemiptera: Anthocoridae), Hippodamia variegata Goeze, 1777, Oenopia conglobata Linnaeus, 1758, Coccinell septempunctata Linnaeus, 1758, Scymnus syriacus (Marseul, 1868) and Adalia bipunctata (Linnaeus, 1758) (Coleoptera: Coccinellidae) and Chrysoperla carnea (Stephens, 1836) (Neuroptera: Chrysopidae). There was a significant difference between treatments in the density of the predators of the pear psyllid (in the first year: $P<0.001$; in the second year: $P<0.001)$. The psyllid specialist predatory bug, $A$. nemoralis, had the highest density among the pear psyllid predators (Figure 3 and 4), but there was not a significant difference between treatments in its population density (in the first year: $P=0.06$; in the second year: $P=0.09$ ). The other predators were generalist predators which were not closely associated with this pest and had lower population than specialist predator, A. nemoralis (Figure 3 and 4).

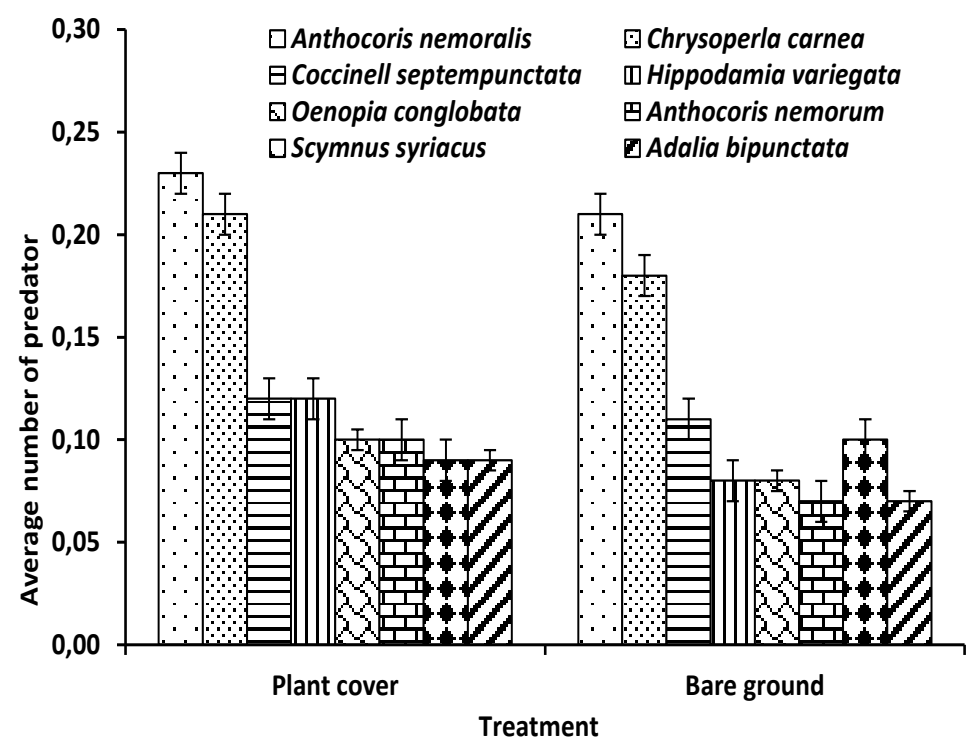

Figure 3: Average number of the pear psyllid predators per sample in the first year 


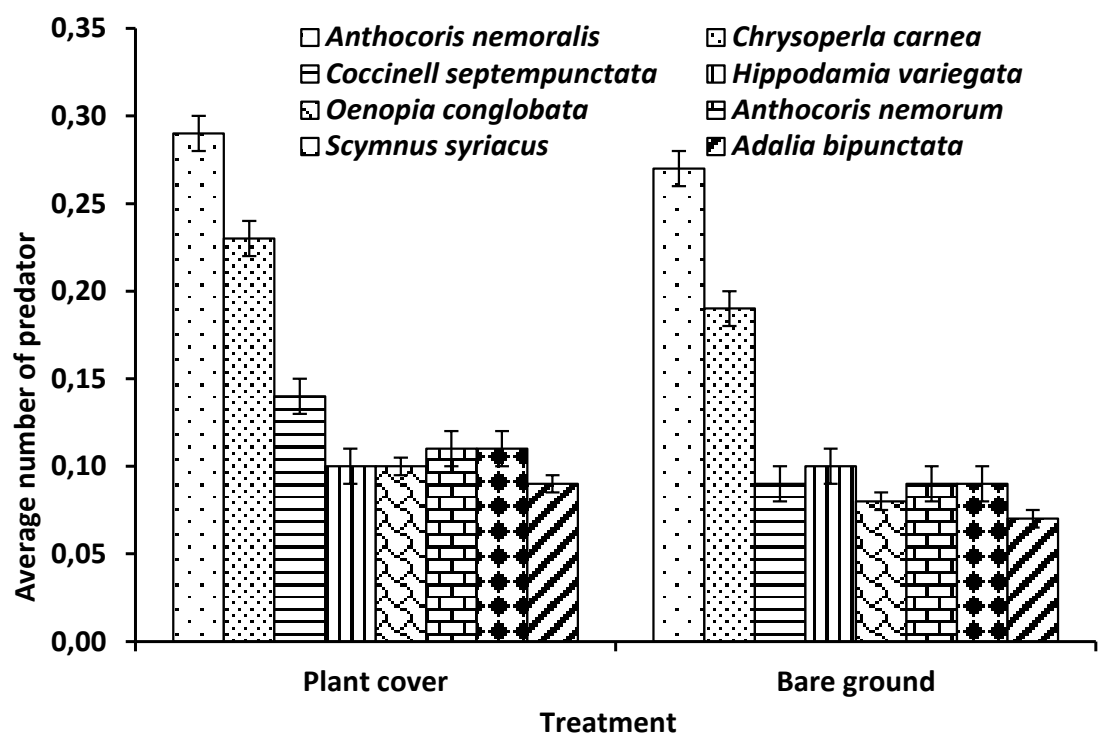

Figure 4: Average number of the pear psyllid predators per sample in the second year

\section{DISCUSSION}

The effect of ground cover on pest control is considered to be positive, null or negative when either the density of the pest arthropod of the fruit tree and fruit damage is lower, equal or higher, respectively, compared with control (Simon et al., 2010). Here, no significant difference was found between density of eggs, nymphs and adults of the pear psyllid in plant cover and bare ground treatments (Fig. 1 and 2). Thus, plant cover had nil effect on the pear psyllid control. Some studies have reported a decrease in herbivore density in the presence of ground cover vegetation (AguilarFenollosa et al., 2011; Altieri and Schmidt, 1986; Beizhou et al., 2011; Irvin et al., 2006; Pfammatter and Vuignier, 1998; Rieux et al., 1999; Wyss, 1995; Wyss et al., 1995), whilst others have found no (Bone et al., 2009; Brown et al., 2008; Danne et al., 2010; Fitzgerald and Solomon, 2004; Horton et al., 2010; Jenser et al., 1999; Nyrop et al., 1994; Paredes et al., 2013; Paredes et al., 2015; Rodriguez et al., 2009) or negative effect (McClure et al., 1982; Meagher and Meyer, 1990a, 1990b; Spellman et al., 2006). All of these studies have shown that selection of the plant cover species in the orchard is important in preventing increased pest population. In pear orchards, both an increase in Anthocorid numbers and a decrease in pear psyllid prey are reported when a grassy ground cover is sown in the alleys compared with bare ground (Rieux et al., 1999). Non-crop vegetation can affect insect populations in a number of ways. They can provide a habitat for beneficial arthropods where they can find physical shelter, alternative hosts, pollen, nectar or water and perhaps a more favorable microclimate than is available within the cropped area, especially if it is a mono-crop (Dyer and Landis, 1997). Here, a significant presence of pear psyllid predators was displayed in plant cover treatment. Despite of the predators belonged to the families Anthocoridae, Coccinellidae and Chrysopidae; their presence had no effect on pear psyllid density. Wilde (1965) found green lacewings to be the most efficient predator of pear psylla followed by anthocorids and ladybird beetles. Rieux et al. (1999) reported that the main beneficial arthropods on pear tree were Empididae (Diptera) and Miridae (Hemiptera) in the natural ground cover area; and Forficulidae (Dermaptera) and Miridae in the bare ground area. Here, lack of pest suppression may be the result of disruption of biological control by alternative prey presence (Koss and Snyder, 2005), asynchrony between pest and their natural enemies (Fagan et al., 2002; Perdikis et al., 2011), lack of specificity and/or intra-guild predation (Paredes et al., 2013). Although plant cover enhanced predators, complex environments may provide pests with refuges and natural enemies may face 
difficulties in locating their prey (Root, 1973; Barbosa, 1998; Finke and Denno, 2006; Hughes and Grabowski 2006). Horton et al. (2010) reported that despite the high densities of predators in the alfalfa cover crop, there was no statistical increase during 3 years of sampling in densities of predators in the canopy of trees having the alfalfa understory, and no effects on psylla densities. No significant correlation was displayed between predator abundance and pear psyllid control in a survey of 8 commercial pear orchards (Simon, 1999). Here, the psyllid specialist predatory bug, A. nemoralis, had the highest density among the pear psyllid predators (Figure 3 and 4). A. nemoralis is the most abundant predator in the pear orchards (Shaltiel and Coll, 2004; Emami et al., 2014) but often migrate into orchards too late and in too small numbers to effect timely and adequate natural regulation of pear psyllid populations (Cross et al., 2010). Most psylla natural enemies are arboreal (Booth, 1992) and relatively scarce in the cover crops (Fye, 1983), therefore, plant covers will not support them (Booth, 1992). Suitable hedgerows such as goat and grey willow, (Salix caprea L. and $S$. cinerea L.), hawthorn, (Crataegus monogyna Jacq.), stinging nettle, (Urtica dioica L.), common ash, (Fraxinus excelsior L.), and hazel, (Corylus avellana L.) (Cross et al., 2010) could act rather than plant covers as reservoirs for the development of pear psylla natural enemies (Booth, 1992). In conclusion, despite plant cover enhanced the population of some predators, this did not lead to reduce pear psyllid abundance, and so is not an optimal form of plant cover for inclusion in integrated pear psyllid management system in pear orchards.

\section{REFERENCES}

Aguilar-Fenollosa E., Pascual-Ruiz S., Hurtado M.A., Jacas J.A. 2011. Efficacy and economics of ground cover management as a conservation biological control strategy against Tetranychus urticae in clementine mandarin orchards. Crop Protection, 30: 1328-1333. doi:10.1016/j.cropro.2011.05.011

Altieri M.A., Schmidt L.L. 1986. The dynamics of colonizing arthropod communities at the interface of abandoned, organic and commercial apple orchards and adjacent woodland habitats. Agriculture. Ecosystems and Environment, 16: 2943. doi:10.1016/0167-8809(86)90073-3

Barbosa, P. 1998. Agroecosystems and conservation biological control. In P. Barbosa (Ed.), Conservation biological control (pp. 39-54). San Diego: Academic Press. doi:10.1016/B978012078147-8/50049-9

Beizhou S., Zhang J., Jinghui H., Hongying W., Yun K., Yuncong Y. 2011.. Temporal dynamics of the arthropod community in pear orchard intercropped with aromatic plants. Pest Management Science, 67: 1107-1114. doi:10.1002/ps.2156

Bone N.J., Thomson L.J., Ridland P.M., Cole P., Hoffmann A.A. 2009. Cover crops in Victorian apple orchards: effects on production, natural enemies and pests across a season. Crop Protection, 28: 675-683. doi:10.1016/j.cropro.2009.03.021

Booth, S.R. 1992. The potential of endemic natural enemies to suppress pear psylla, Cacopsylla pyricola Förster, in the Hood River Valley
(Unpublished doctoral dissertation). Oregon State University, Corvallis.

Brown M.W., Mathews C.R., Krawczyk G. 2008. Analyzing the results of biodiversity experiments: enhancing parasitism of tufted apple bud moth. Proceedings International Conference Integrated Fruit Production. Avignon, France, p 6.

Bugg R.L. 1991. Cover crops and control of arthropod pests of agriculture. In W. L. Hargrove (Ed.) Cover Crops for Clean Water. The proceedings of an international conference (pp. 157-163). West Tennessee Experiment Station, Soil and Water Conservation Society. Ankeny, Iowa.

Bugg R.L. 1992. Using cover crops to manage arthropods on truck farms. HortScience, 27: 741745 .

Bugg R.L., Waddington C. 1994. Using cover crops to manage arthropod pests of orchards: a review. Agriculture, Ecosystems and Environment, 50: 1128. doi:0.1016/0167-8809(94)90121-X

Burts E.D., Retan A.H. 1973. Detection of pear psylla. Washington State University Cooperative Extension Service. Mimeo 3069.

Cross J., Nagy C., Batki M., Linka J. 2010. Conservation biocontrol of pear psyllids. Mitteilungen Klosterneuburg, 60: 403-412.

Danne A., Thomson L.J., Sharley D.J., Penfold C.M., Hoffmann A.A. 2010. Effects of native grass cover crops on beneficial and pest invertebrates in 
Australian vineyards. Environmental Entomology, 39: 970-978. doi:10.1603/EN09144

Dyer L.E., Landis D.A. 1997. Influence of non-crop habitats on the distribution of Eriborus terebrans (Hymenoptera: Ichneumonidae) in corn fields. Environmental Entomology, 26: 924-932. doi:10.1093/ee/26.4.924

Emami M.S. 2014. Studies on the tritrophic interactions between pear psylla Cacopsylla pyricola (Foerster) and predatory bug Anthocoris nemoralis (Fabricius) (Unpublished doctoral dissertation). Shahid Chamran University of Ahvaz, Iran.

Emami M.S., Shishehbor P., Karimzadeh J. 2014. The influences of plant resistance on predation rate of Anthocoris nemoralis (Fabricius) on Cacopsylla pyricola (Förster). Archives of Phytopathology and Plant Protection, 47: 2043-2050. doi:10.1080/03235408.2013.868695

Fagan W.F., Lewis M.A., Neubert M.G., van den Driessche P. 2002. Invasion theory and biological control. Ecological Letter, 5: 148-157. doi:10.1046/j.1461-0248.2002.0_285.x

Finke D.L., Denno R.F. 2006. Spatial refuge from intraguild predation: implications for prey suppression and trophic cascades. Oecologia, 149: 65-275. doi:10.1007/s00442-006-0443-y

Fitzgerald J.D., Solomon M.G. 2004. Can flowering plants enhance numbers of beneficial arthropods in UK apple and pear orchards? Biocontrol Science and Technology, 14: 291-300. doi:10.1080/09583150410001665178

Flint M.L. 1998. Pests of the garden and small farm: a grower's guide to using less pesticide. Oakland, University of California Press.

Fye R.E. 1983. Cover crop manipulation for building pear psylla (Homoptera: Psyllidae) predator populations in pear orchards. Journal of Economic Entomology, 76: 306-310. doi:10.1093/jee/76.2.306

Hargrove W.L. 1991. Cover Crops for Clean Water. The proceedings of an international conference, West Tennessee Experiment Station. Soil and Water Conservation Society, Ankeny, Iowa.

Horton D., Unruh T., Jones V. 2010. Quantifying biological control of pear psylla in a cover crop system. Final Project Report, PR-07-702, Available from: http://www.tfrec.wsu.edu/pdfs/P1963.pdf

Horton D.R. 1999. Monitoring of pear psylla for pest management decisions and research. Integrated Pest Management Review, 4: 1-20. doi:10.1023/A:1009602513263
Horton D.R., Broers D.A., Lewis R.R., Granatstein D., Richard S.Z, Unruh T.R., Moldenke A.R., Brown J.J. 2003. Effects of mowing frequency on densities of natural enemies in three Pacific Northwest pear orchards. Entomologia Experimentalis et Applicata, 106: 135-145. doi:10.1046/j.15707458.2003.00018.x

Hughes A.R., Grabowski J.H. 2006. Habitat context influences predator interference interactions and the strength of resource partitioning. Oecologia, 149: 256-264. doi:10.1007/s00442-006-0439-7

Irvin N.A., Scarratt S.L., Wratten S.D., Frampton C.M., Chapman R.B., Tylianakis J.M. 2006. The effects of floral understoreys on parasitism of leafrollers (Lepidoptera: Tortricidae) on apples in New Zealand. Agricultural and Forest Entomology, 8: 25-34. doi:10.1111/j.1461-9555.2006.00285.x

Jenser G., Balázs K., Erdélyi Cs., Haltrich A., Kádár F., Kozár F., Markó V., Rácz V., Samu F. 1999. Changes in arthropod population composition in IPM apple orchards under continental climatic conditions in Hungary. Agriculture. Ecosystems and Environment, 73:141-154. doi:10.1016/S01678809(99)00023-7

Koss A.M., Snyder W.E. 2005. Alternative prey disrupts biocontrol by a guild of generalist predators. Biological Control, 32: 243-251. doi:10.1016/j.biocontrol.2004.10.002

Letourneau D.K., Jedlicka J.A., Bothwell S.G., Moreno C.R. 2009. Effects of natural enemy biodiversity on the suppression of arthropod herbivores in terrestrial ecosystems. Annual Review of Ecology, Evolution, and Systematics, 40: 573-592. doi:10.1146/annurev.ecolsys.110308.120320

MacRae R.J., Mehuys G.R. 1985. The effect of green manuring on the physical properties of temperatearea soils. Advances in Soil Science, 3: 71-94. doi:10.1007/978-1-4612-5090-6_2

McClure M.S., Andreadis T.G., Lacy G.H. 1982. Manipulating orchard ground cover to reduce invasion by leafhopper vectors of peach X-disease. Journal of Economic Entomology, 75: 64-68. doi:10.1093/jee/75.1.64

Meagher R.L., Meyer J.R. 1990a. Influence of ground cover and herbicide treatments on Tetranychus urticae populations in peach orchards. Experimental and Applied Acarology, 9: 149-158. doi:10.1007/BF01193424

Meagher R.L., Meyer J.R. 1990b. Effect of ground cover management on certain abiotic and biotic interactions in peach orchard ecosystems. Crop Protection, 9: 65-72. doi:10.1016/02612194(90)90048-C

Acta agriculturae Slovenica, 109 - 1, marec 2017 
Nyrop J.P., Minns J.C., Herring C.P. 1994. Influence of ground cover on dynamics of Amblyseius fallacis Garman (Acarina: Phytoseiidae) in New York apple orchards. Agriculture, Ecosystems and Environment, 50: 61-72. doi:10.1016/01678809(94)90125-2

Paredes D., Cayuela L., Campos M. 2013. Synergistic effects of ground cover and adjacent vegetation on natural enemies of olive insect pests. Agriculture, Ecosystems and Environment, 173:.72-80.

Paredes D., Cayuela L., Gurr GM., Campos M. 2015. Is ground cover vegetation an effective biological control enhancement strategy against olive pests? PLoS ONE 10(2): e0117265. doi:10.1371/journal.pone.0117265

Perdikis D., Fantinou A., Lykouressis D. 2011. Enhancing pest control in annual crops by conservation of predatory Heteroptera. Biological Control, 59: 13-21. doi:10.1016/j.biocontrol.2011.03.014

Pfammatter W., Vuignier R. 1998. Amélioration de la lutte biologique dans les cultures fruitières au moyen de bandes de plantes sauvages. 1er Colloque transnational sur les luttes biologique, intégrée et raisonnée, Région Nord-Pas-de-Calais, Lille, France, p. 71-72.

Rieux R., Simon S., Defrance H. 1999. Role of hedgerows and ground cover management on arthropod populations in pear orchards. Agriculture, Ecosystems and Environment, 73:.129-140.

Rodriguez E, Gonzalez B., Campos M. 2009. Effects of cereal cover crops on the main insect pests in Spanish olive orchards. Journal of Pest Science, 82: 179-185. doi:10.1007/s10340-008-0237-6

Root R.B. 1973. Organization of a plant-arthropod association in simple and diverse habitats: the fauna of collards (Brassica oleracea). Ecological Monographs, 43: 94-125. doi:10.2307/1942161

Shaltiel L. Coll M. 2004. Reduction of pear psylla damage by the predatory bug Anthocoris nemoralis
(Heteroptera: Anthocoridae): the importance of orchard colonization time and neighboring vegetation. Biocontrol Science and Technology, 14; 811-821. doi:10.1080/09583150410001720662

Simon S. 1999. Incidence de l'environnement végétal sur les populations d'arthropodes du verger de poiriers. Thèse de doctorat de l'Université de Montpellier 2, France.

Simon S., Bouvier J.C., Debras J.F., Sauphanor B. 2010. Biodiversity and pest management in orchard systems: A review. Agronomy for Sustainable Development, 30: 139-152. doi:10.1051/agro/2009013

Spellman B., Brown M.W., Mathews C.R. 2006. Effect of floral and extrafloral resources on predation of Aphis spiraecola by Harmonia axyridis on apple. BioControl, 51: 715-724. doi:10.1007/s10526-0055252-4

Wilde W.H.A. 1960. Bionomics of the pear psylia, Psylia pyricola Foerster, in pear orchards of the Kootenay Valley of British Columbia. Canadian Entomologist, 94: 845-849. doi:10.4039/Ent948458

Wilde W.H.A. 1965. The pear psylia, Psylla pyricola Foerster, in Ontario. Entomological Society of Ontario, 95: 5-10.

Wyss E. 1995. The effects of weed strips on aphids and aphidophagous predators in an apple orchard. Entomologia Experimentalis et Applicata, 75: 4349. doi:10.1111/j.1570-7458.1995.tb01908.x

Wyss E., Niggli U., Nentwig W. 1995. The impact of spiders on aphid populations in a strip-managed apple orchard. Journal of Applied Entomology, 119: $\quad 473-478 . \quad$ doi:10.1111/j.14390418.1995.tb01320.x

Zandstra B.H., Motooka P.S. 1978. Beneficial effects of weeds in pest management: a review. PANS, 24: 333-338. doi:10.1080/09670877809411634 